Diabetologia 2, 237-247 (1966)

\title{
ORIGINALS
}

\section{Carbohydrate Metabolism and Lipid Storage and Breakdown in Diabetes*}

\author{
The Minkowski Award Lecture delivered on July 6, 1966 before the European Association for the Study of Dia- \\ betes, at Aarhus, Denmark
}

Philit J. Raxdle

Department of Biochemistry, University of Bristol

Received August 15, 1966

\begin{abstract}
Summary. Interactions between the metabolism of glucose and lipids provide the basis for a number of metabolic disturbances which have been observed in clinical and experimental diabetes. Particular examples are abnormalities which may be seen in the storage and mobilisation of lipid and in the relative contribution of glucose and fatty acid to energy needs. The concept of a Glucose Fatty Acid Cycle is reviewed and forms the basis for recent studies which are outlined. An essential feature of the Cycle is the proposal that the normal relationship between glucose and fatty acid metabolism is reciprocal and not dependent; and that the augmented release of fatty acids for oxidation in muscle and other tissues in diabetes is not primarily due to defective glucose metabolism. The release and oxidation of fatty acids may depend upon lipolysis which may be directly regulated by hormone action and not dependent upon glucose metabolism. It can also depend upon esterification of fatty acids which may involve the metabolism of glucose to glycerol phosphate. Evidence is presented that lipid mobilization in the alloxan-diabetic rat which may be insensitive to inhibition by insulin action is primarily dependent upon activation of lipolysis. Although the concentration of glycerol phosphate is diminished in muscle in this form of diabetos this is not a consequence of diminishod glucose uptake and it is moreover associated with an increased rate of esterifi. cation of fatty acids. In adipose tissue the concentration of glycerol phosphate is not reduced, even though glucose uptake is diminished, and the rate of esterification of fatty acid is accelerated. The concentration of triglyceride in muscle is increased in alloxan-diabetes in the rat and this may be attributed to increased mobilisation of fatty acids from adipose tissue associated with increased esterification to triglyceride in muscle. An increased rate of glucose uptake may be an important factor leading to triglyceride storage in adipose tissue and possibly in muscle when insulin acts on these tissues in the normal animal. The evidence for the possibility that lipid mobilisation may have consequential effects on carbohydrate metabolism and insulin sensitivity in alloxan-diabetes has been briefly reviewed and suggestions made for future studies. It is suggested that our understanding of the mechanisms which may control insulin sensitivity is incomplete, and as a consequence the quantitative importance of the contributions which fatty acid oxidation may make to insulin insensitivity in diabetes remains to be established.
\end{abstract}

* Some of this material also formed the basis for parts of the Banting Memorial Lecture of the British Diabetic Association delivered at the Medical School of the University of Bristol, England, in October, 1965. The studies reported have been supported by grants from the British Diabetic Association, the British Insulin Manufacturers, The Medical Research Council, the Science Research Council and the Royal Society.
Relations du métabolisme des hydrates de carbone avec le stockage et la dégradation des lipides dans le diabète.

Résumé. Les interactions entre le métabolisme du glucose et des lipides fournissent la base d'un certain nombre de troubles métaboliques qui ont été observés dans le diabète clinique et expérimental. Des exemples particuliers sont des anomalies qui peuvent être observées dans le stockage et la mobilisation de la graisse et dans la contribution relative du glucose et de l'acide gras aux besoins énergétiques. Le concept d'un Cycle Glucose Acide Gras est passé en revue et forme la base des études récentes dont on donne la description générale. Un trait essentiel du Cycle est l'hypothèse que la relation normale entre le métabolisme du glucose et le métabolisme des acides gras est réciproque et non dépendante; et que la libération accrue des acides gras pour l'oxydation dans le muscle et les autres tissus, observée dans le diabète n'est pas due primitivement à un métabolisme défectueux du glucose. La libération et l'oxydation des acides gras peuvent dépendre de la lipolyse qui peut être régulée directement par l'action hormonale et ne pas dépendre du métabolisme du glucose. Elles peuvent aussi dépendre de l'estérification des acides gras, qui peut impliquer le métabolisme du glucose jusqu'au glycérol phosphate. La preuve est présentée que la mobilisation des lipides chez le rat diabétique alloxanique qui peut se montrer insensible à l'action inhibitrice de l'insuline, dépend primitivement de l'activation de la lipolyse. Bien que la concentration du glycérol phosphate soit diminuée dans le muscle dans cette forme de diabète, ceci n'est pas la conséquence de la diminution de la captation du glucose; elle est d'ailleurs associée à un accroissement de la vitesse d'estérification des acides gras. Dans le tissu adipeux la concentration en glycérol phosphate n'est pas réduite, bien que la captation de glucose soit diminuée, et la vitesse d'estérification des acides gras est accélérée. La concentration de triglycéride dans le muscle est accrue dans le diabète alloxanique du rat et ceci peut être attribué à un accroissement de la mobilisation des acides gras à partir du tissu adipeux, associé à un accroissement de l'estérification en triglycéride dans le muscle. Une augmentation de la vitesse de captation du glucose peut être un facteur important conduisant au stockage du triglycéride dans le tissu adipeux et peut-être dans le muscle lorsque l'insuline agit sur ces tissus chez l'animal normal. On a brièvement passé en revue les arguments établissant la possibilité que la mobilisation des lipides entraîne des effets sur le métabolisme des hydrates de carbone et sur la sensibilité à l'insuline dans le diabète post-alloxanique; des suggestions sont faites pour des études ultérieures. Il est suggéré que notre compréhension des mécanismes qui peuvent contrôler la sensibilité à l'insuline est incomplète et en conséquence, l'importance quantitative des contributions que l'oxydation des acides gras peut apporter à l'insensibilité à l'insuline dans le diabète demeure à établir. 
Kohlenhydratstoffwechsel, Fettspeicherung und Fettabbau bei Diabetes mellitus.

Zusammenfassung. Die Zusammenhänge zwischen Glucose- und Fettstoffwechsel sind die Basis für eine Reihe von Stoffwechselstörungen, die beim klinischen und experimentellen Diabetes beobachtet wurden. Die Störungen, die man in der Fettspeicherung und Fettmobilisation und in dem relativen Anteil der Glucose und der Fettsäuren am Energiestoffwechsel sieht, sind spezielle Beispiele. Die Annahme eines Glucose-Fettsäure-Cyclus (Glucose Fatty Acid Cycle) wird dargestellt. Diese bildet den Ausgangspunkt für neuere Untersuchungen, die beschrieben werden. Ein wesentlicher Zug dieses Cyclus ist die Annahme, daß die normalen Beziehungen zwischen Glucose- und Fettsäurestoffwechsel umkehrbar und unabhängig sind und daß beim Diabetes die vermehrte Freisetzung von Fettsäuren für die Oxydation im Muskel und anderen Geweben primär nicht auf eine Störung des Glucosestoffwechsels zurückzuführen ist. Vielmehr kann die Freisetzung und Oxydation der Fettsäuren von einer Lipolyse abhängig sein, die direkt durch hormonelle Wirkung gesteuert wird und vom Glucosestoffwechsel nicht abhängig ist. Sie kann auch von der Veresterung der Fettsäuren abhängig sein, die mit dem Abbau von Glucose zu Glycerinphosphat in Zusammenhang steht. Es werden Hinweise vorgelegt, die zeigen, daß die Fettmobilisation bei der alloxandiabetischen Ratte, die durch Insulinwirkung nicht gehemmt werden kann, primär von einer Aktivierung der Lipolyse abhängt. Obwohl die Konzentration von Glycerinphosphat bei dieser Form des Diabetes im Muskel vermindert ist, ist das nicht eine Folge der verminderten Glucoseaufnahme, sondern ist vielmehr mit einer gesteigerten Veresterungsrate der Fettsäuren verbunden. Obwohl die Glucoseaufnahme vermindert ist, ist die Konzentration des Glycerinphosphates im Fettgewebe nicht verringert und die Veresterungsrate der Fettsäuren sogar vermehrt. Die Konzentration der Triglyceride ist beim Alloxandiabetes der Ratte im Muskel vermehrt. Das kann auf die gesteigerte Mobilisation von Fettsäuren aus dem Fettgewebe verbunden mit einer vermehrten Veresterung zu Triglyceriden im Muskel zurückgeführt werden. Eine gesteigerte Glucoseaufnahme kann ein wichtiger Faktor für eine Triglyceridspeicherung im Fettgewebe und möglicherweise auch im Muskel sein, wenn beim Normaltier Insulin auf diese Gewebe einwirkt. Die Hinweise dafür, daß möglicherweise die Fettmobilisation nachfolgende Wirkungen auf den Kohlenhydratstoffwechsel und die Insulinempfindlichkeit beim Alloxandiabetes hat, werden kurz geschildert und Vermutungen für weitere Untersuchungen geäußert. Es wird angenommen, daß unsere Einsicht in den Steuerungsmechanismus der Insulinempfindlichkeit unvollständig ist und daß deshalb die quantitative $\mathrm{Be}$ deutung der Fettsäureoxydation auf die Insulinunempfindlichkeit beim Diabetes noch aufzuklären bleibt.
In clinical and experimental diabetes the normal relationships between glucose and lipid metabolism may be disturbed in a number of ways. Obesity, which may be associated with accelerated breakdown of triglyceride, is a common finding in maturity-onset diabetes without deficiency of circulating insulin. With the development of insulin deficiency wasting of adipose tissue and ketosis may predominate because lipogenesis is inhibited and lipid breakdown accentuated. In both clinical and experimental diabetes fatty acid may be a major respiratory fuel in muscle and other tissues, even when glucose and insulin are freely available. In the normal animal, on the other hand, glucose may be a major fuel after carbohydrate intake and fatty acid a major fuel in periods between meals.

Current research into the relationships between glucose and lipid metabolism owes much of its impetus to developments in our knowledge of the metabolic pathways involved. Particular mention may be made of the discovery of coenzyme A and its metabolic derivatives as a result of the studies of LrPMANN, Lynen and Baddiley (LipMans, 1946, 1954; Lyxen, 1954; LYNEN et al., 1951; BADDILEY, 1955); the recognition of the role of glycerol phosphate and of glucose metabolism in the biosynthesis of triglyceride and phospholipids by WeIss and KENNedy (1956), Smith et al. (1957) and WIELAND and Suyter (1957); the discovery of plasma free fatty acids and their role in the transport of fatty acids from adipose tissue glycerides to tissues such as muscle by LAURELL (1956), DoLe (1956) and Gordon and Cherkes (1956); and the recognition that adipose tissue is a major site of lipogenesis, free fatty acid release and hormone action by Wertetetmer and Shaptro (1948), Werthetmer and SHAFrIR (1960), HAusBerger et al. (1954), KraHL (1951), Rexold et al. (1965), CAHILl et al. (1959), GORDON and Cherkes (1958) and WHITE and ENGEL (1958).

In a tissue such as muscle, which under normal conditions has an abundant supply of respiratory fuels, oxygen consumption is determined by the work done and not by the supply of respiratory fuel. Accordingly if more than one respiratory fuel is available they may compete for the oxygen consumed. This idea of substrate competition was first put forward for amino acids and glucose in kidney by KreBs (1935) and subsequently extended to competition between glucose and ketone bodies or fatty acids in muscle by DruRY and Wick (1953), WILLIAMSON and KreBs (1961) and SHIPP et al. (1961).

My own interest in the interrelations of glucose and fatty acid metabolism began in 1960 with the observation (albeit fortuitous) that phosphofructokinase (PFK) is inhibited in the perfused heart by starvation of the rat (NEWSHOLME and RANDLE, 1961) or induction of alloxan-diabetes (REgEN et al., 1964; Newsholme and RANDLE, 1964).

\section{The Glucose Fatty Acid Cycle and Insulin Sensitivity}

In muscles from alloxan-diabetic rats three defects in the metabolism of glucose, which may lead to insulin insensitivity, are well recognised. These are defects in the oxidation of pyruvate (due to inhibition of pyruvate dehydrogenase, $\mathrm{PDH}$ ), in glucolysis (due to inhibition of phosphofructokinase, PFK) and in glucose phosphorylation (due to inhibition of hexokinase, HK) 
(Kipnis, 1959; Morgan et al., 1961; Regen et al., 1964; Newsholme and RaYDLE, 1964; VILLEE and Hastings, 1949 ; Pearson et al. 1949; Garland et al., 1962, 1964). An additional defect which has not been studied in detail is the diminished ability of insulin to stimulate membrane transport of glucose. With the exception of PDH with which endocrine control has not been fully investigated these defects may result from actions of growth hormone and corticosteroids in an insulin deficient animal (PARK et al., 1961; REGEN et al., 1964; Newsholme and RANDle, 1964). For this reason they may be related fundamentally to the antagonism between growth hormone and corticosteroids on the one hand and insulin which is seen in many species including man. It was shown in further studies that the in vitro provision of fatty acids or ketone bodies for respiration in normal muscle leads to similar defects in the phosphorylation, glucolysis and oxidation of glucose which could be attributed to inhibition of HK, PFK and PDH. Enzymic mechanisms for the inhibitory effects of fatty acid oxidation and of alloxan diabetes on glucose metabolism and insulin sensitivity were subsequently detailed. It was suggested that the fundamental basis for the effects of fatty acid oxidation and in all probability for those of alloxan-diabetes was an increase in the mitochondrial concentration ratios of acetyl $\mathrm{CoA} / \mathrm{CoA}$ and $\mathrm{NADH}_{2} / \mathrm{NAD}$ resulting from the oxidation of fatty acids to acetyl CoA. These changes may lead directly to inhibition of PDH and indirectly through citrate synthesis and glucose 6-phosphate accumulation to inhibition of PFK and HK. The evidence for these points, which are summarised in Fig. 1, has been detailed in papers by Newsholme et al. (1962); Newsholme and RANDLE (1964); GarLand et al. (1964); RaNDLE et al. (1964a, 1966); Garland and Randele (1964a, b); Evans et al. (1963); Nicholls and GarLaNd (1966); Garland et al. (1963); Parmeggiani and Bowman (1963); Pogson and Randef (1966a, b); RaNDLE et al., (1966). These findings called into question the idea that the release and oxidation of fatty acids in diabetes is a consequence of diminished uptake and oxidation of glucose and suggested on the contrary that the release and oxidation of fatty acids might have consequential effects on the metabolism of glucose.

These studies led in association with P. B. GarLAND, C.N. Hales and E.A. Newsholme to the suggestion that the normal relationship between glucose and fatty acid metabolism is essentially reciprocal and not dependent. The metabolism of glucose in muscle and adipose tissue may restrain the release and oxidation of fatty acids, whereas the release and oxidation of fatty acids may impair the uptake and oxidation of glucose in muscle and enhance the formation of glucose in the liver. The name Glucose Fatty Acid Cycle has been proposed for this relationship (RANDLE et al., 1963). The cycle was envisaged as a primitive control mechanism subject to modification by hormone action and concerned with the maintenance of plasma glucose concentration in animals that feed intermittently. It

\section{MUSCLE}

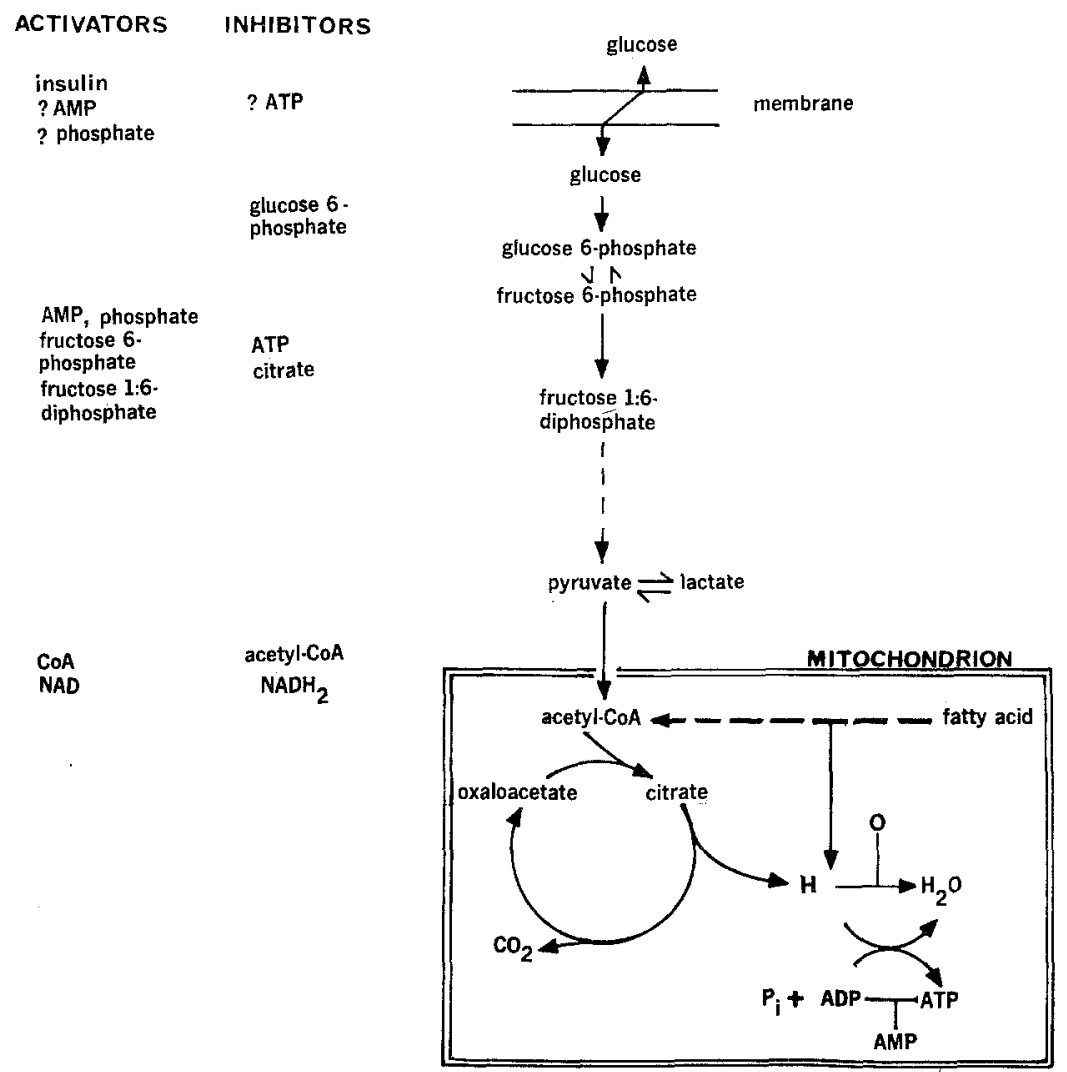

Fig. 1. Control of glucose metabolism in muscle by the oxidation of fatty acids

was suggested that in diabetes the effects of growth hormone, corticosteroids, insulin deficiency and perhaps other factors may modify the cycle by accelerating the release and oxidation of fatty acids. It was envisaged that this could be an important signal for the development of insulin insensitivity, glucose intolerance and impaired glucose oxidation (RANDLE et al., 1963, 1964b; HaLes and Rander, 1963). The inhibitory effects of fatty acid oxidation on glucose consumption could thus provide the basis for one form of insulin antagonism where a biochemical mechanism can be detailed. This does not however establish its quantitative significance or exclude other mechanisms. An essential feature of this concept was the idea that deficiencies in the 
uptake and metabolism of glucose were not primarily responsible for the augmented release and oxidation of fatty acids in diabetes.

\section{Lipid synthesis and breakdown and the oxidation of fatty acids}

Because the oxidation of fatty acids may have inhibitory effects on the metabolism of glucose in muscle, it has been of some conceptual importance to define the extent to which glucose metabolism may control free fatty acid release. In muscle, the concentration of free fatty acids and of their acyl CoA derivatives may be correlated with the rate of fatty acid oxidation (GARLAND and RANDLE, 1964b). The reactions which may regulate these concentrations are shown in Fig. 2. With muscle in vitro the concentrations of fatty acids and their acyl CoA derivatives may depend on the relative rates at which triglycerides (and possibly phospholipids) are broken down by lipolysis
MUSCLE

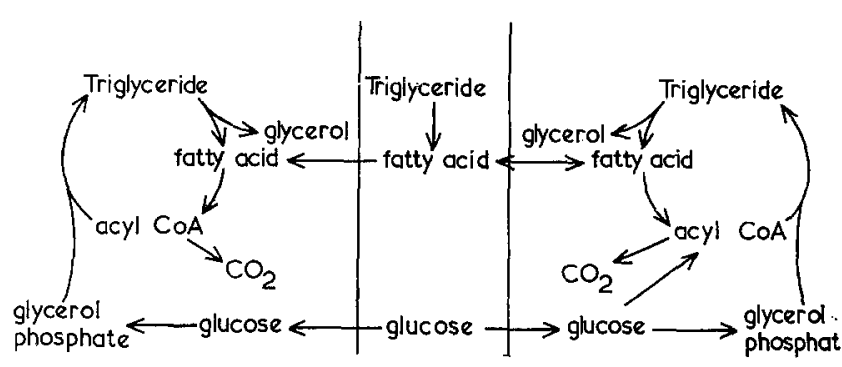

inhibitory effect (GARLAND and RANDLe, 1962, 1963; AsHLEY and RANDLE, unpublished work). Lipolysis is also activated in muscle by growth hormone and corticosteroid in the absence of insulin in the alloxan-diabetic rat in vivo but it is not known whether the effect of these hormones on muscle lipolysis is direct (GARLAND and RANDLE, 1962, 1963, 1964b). Changes in the rate of lipolysis which do not appear to be dependent upon alterations in the rate of glucose metabolism are thus capable of explaining the accelerated oxidation of fatty acids in muscle and other tissues in the diabetic animal. In more recent studies which have been made in collaboration with R.M. Denton and C.I. Pogson some consideration has been given to the possible role of glucose metabolism and esterification of fatty acid in the control of free fatty acid release in muscle and adipose tissue.

\section{Glucose utilisation and the control of glycerol phosphate concentration and esterification of fatty acids}

In muscle and in white adipose tissue in the rat, glycerol phosphate for triglyceride and phospholipid synthesis is apparently formed from glucose. There is as a consequence the possibility that glucose uptake may, by determining the glycerol phosphate concentration, regulate the rate of esterification of fatty acid. Such a relationship, if it exists, could provide a biochemical basis for the idea that diminished glucose uptake in diabetes may contribute to augmented release and oxidation of fatty acid.

Fig. 2. Reactions involved in the storage, release and oxidation of fatty acids

and resynthesised by esterification (by reaction of acyl CoA with glycerol phosphate). The intracellular concentrations of free fatty acids and their acyl CoA derivatives in muscle in vivo may be dependent additionally on the plasma concentration of free fatty acids. The relative rates of lipolysis and esterification of fatty acids in adipose tissue and the rate of bydrolysis of plasma triglycerides may thus contribute in vivo through their effects on the plasma concer tration (see Fig. 2). Extensive in vitro studies with adipose tissue have emphasised the importance of lipolysis in regulating free fatty acid release. In this tissue the control of lipolysis by hormones is apparently direct and may not depend upon glucose metabolism. Lipolysis appears to be acutely inhibited by insulin and accelerated by adrenaline (JUNGAS and BALI, 1963; MAhrer et al., 1964; LynN et al., 1960; LEBOEUF et al., 1959; RIZaCK, 1961; Hollenberg et al., 1961). Moreover growth hormone and corticosteroids in the absence of insulin may accelerate lipolysis after a latent period of 2 to $3 \mathrm{~h}$ (FAIN et al., 1965). This observation may explain the growth hormone and corticosteroid dependent activation of lipolysis in adipose tissue which develops in alloxan-diabetic rats in vivo (GARLAND and RANDLE, 1964b). In muscle lipolysis is activated by adrenaline but insulin has little if any

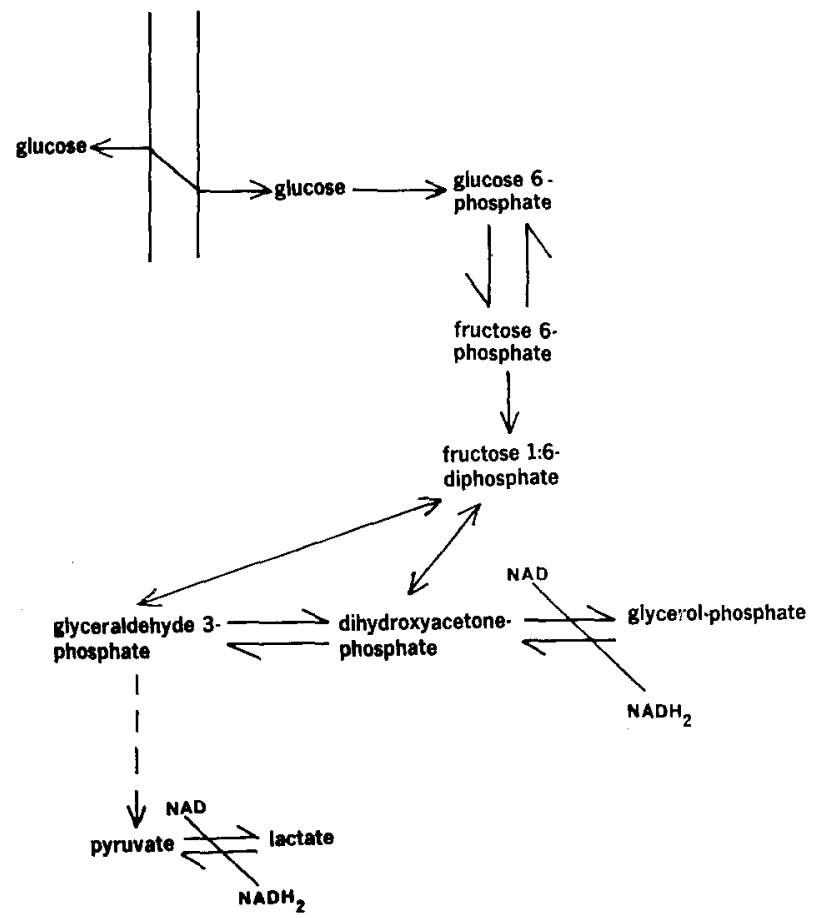

Fig. 3. Reactions involved in the formation of glycerol phosphate and the control of glycerol phosphate concentration in muscle and white adipose tissue

The reactions which may control the formation and the concentration of glycerol phosphate in muscle and 
white adipose tissue are shown in Fig. 3. If equilibrium conditions apply, the concentration of glycerol phosphate may be controlled by that of its precursor (dihydroxyacetone phosphate) and by the cytoplasmic concentration ratio of $\mathrm{NADH}_{2} / \mathrm{NAD}$. The enzyme phosphofructokinase (PFK), which catalyses one of the reactions on the pathway between glucose and glycerol phosphate in muscle and adipose tissue, may contribute to the control of glycerol phosphate concentration in two ways. There is evidence that the activity of PFK may control the concentration of fructose 1:6-diphosphate and hence of dihydroxyacetone phosphate in muscle and presumably in adipose tissue (NEWsholme and Randle, 1964; Denton et al., 1966; Denton and Randele, 1966). The activity of PFK may also control

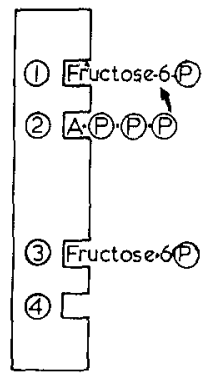
control of the cytoplasmic ratio of $\mathrm{NADH}_{2} / \mathrm{NAD}$ in the two tissues. Another factor in the control of this ratio may be the rate of oxidation of eytoplasmic $\mathrm{NADH}_{2}$ or of reduction of cytoplasmic NAD by mitochondrial metabolism.

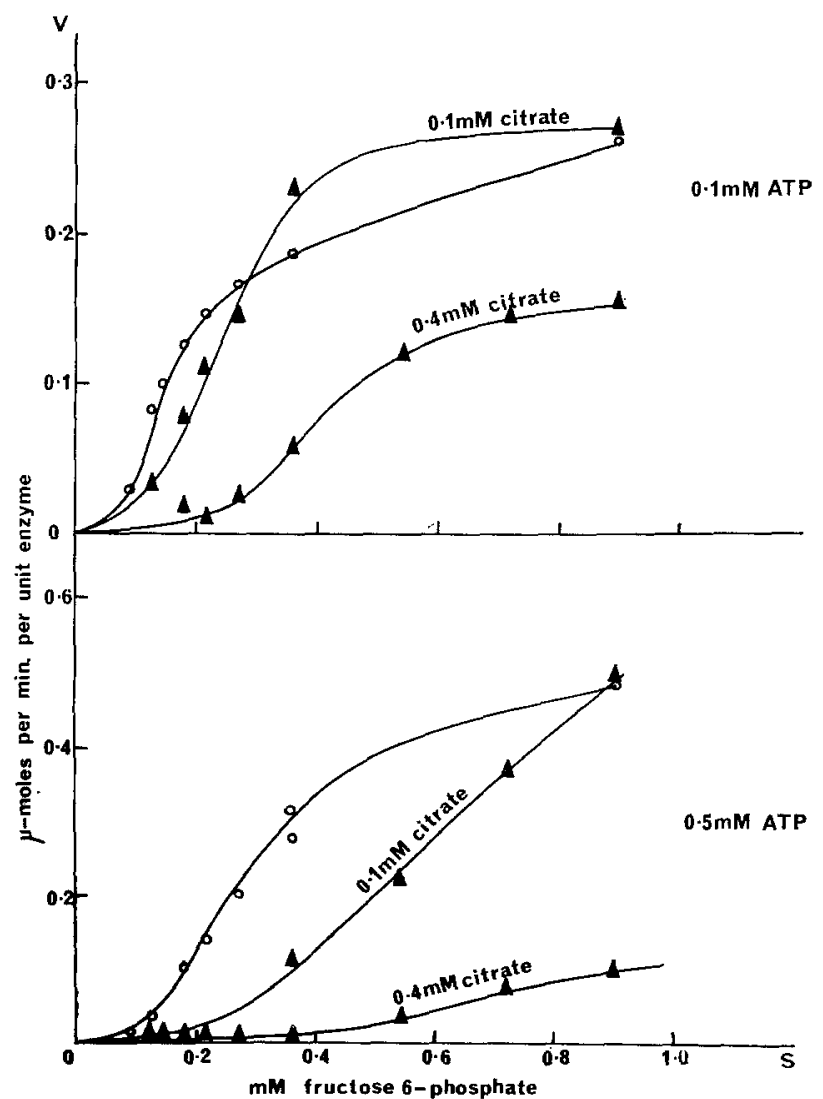

Fig. 4. Interactions of ATP, citrate and fructose 6-phosphate in the control of rat heart phosphofructokinase activity: upper panel $0.1 \mathrm{mM}$ ATP; Iower panel $0.5 \mathrm{mM}$ ATP; $0-0$, no citrate; $\Delta-\Delta, 0.1 \mathrm{mM}$ or $0.4 \mathrm{mM}$ citrate as shown. Data of POGSON and RANDLE (1966a)

The control of PFK in muscle and adipose tissue appears to involve three groups of signals. These are
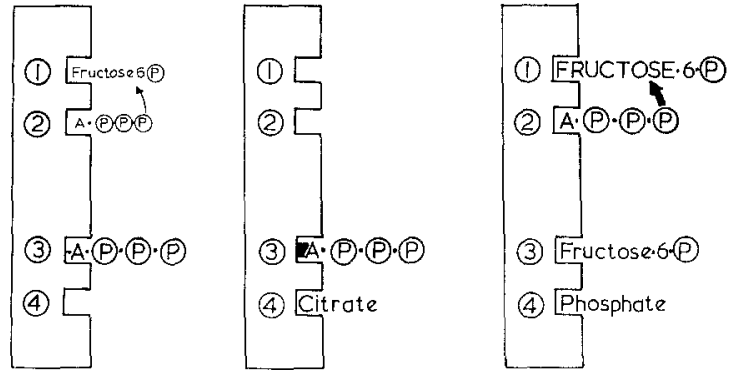

Fig. 5. Model for regulation of rat heart phosphofructokinase

(1) (2) Active sites (3) Prime regulator site(s) (4) Secondary regulator site(s). Data of POGSON and RANDLE (1966a)

the concentration of fructose 6-phosphate, the concentration of citrate, and the relative concentrations of ATP and of $5^{\prime}$ AMP, cyclic $3^{\prime} 5^{\prime}$ AMP and inorganic phosphate (Passonneau and Lowry, 1962; Pogson and Randee, 1966 a ; Denton and Randle, 1966). The control of PFK from rat heart by fructose 6-phosphate,

ATP and citrate concentrations is illustrated in Fig. 4. In the absence of citrate and with concentrations of ATP above $0.08 \mathrm{mM}$, curves relating reaction velocity to fructose 6-phosphate concentration are sigmoid. Because of this relationship there is a range where a relatively small increase in fructose 6-phosphate concentration may "switch on" the enzyme and produce a relatively large increase in reaction velocity. In the presence of citrate which is inhibitory the sensitivity of the enzyme to fructose 6-phosphate concentration is markedly reduced. Fig. 5 shows a model which may account for these properties of PFK. It is envisaged that there are in addition to the active sites, two orders of regulator site(s). The primary regulator site(s) may mediate the inhibitory effect of ATP and its reversal by fructose 6-phosphate. The secondary regulator site(s) may mediate inhibition by citrate and activation by agents such as phosphate and it is suggested that they may influence the binding of ATP or fructose 6-phosphate by the primary regulator site(s). Evidence for this model has been given for the rat heart enzyme by Pogson and RANDLE (1966a).

The properties of PFK suggest one mechanism by which glucose uptake may influence the formation and concentration of glycerol phosphate and the esterification of fatty acids. By influencing the concentration of fructose 6-phosphate, glucose uptake may influence PFK activity and glycerol phosphate formation. Some measurements of the concentrations of glucose 6-phosphate, fructose 6-phosphate and glycerol phosphate and the rates of glucose uptake and flow of carbon from glucose to glyceride glycerol and glycerol in rat muscle and epididymal adipose tissue are given in Table 1 . The table lacks data for the effects of insulin on carbon flow in muscle, which has yet to be measured. It also lacks data for the concentrations of fructose 6-phosphate in adipose tissue, which were too low for reliable assay. The assumption will be made that in adipose tissue, as in muscle, the concentration of fructose 6-phosphate will 
follow that of glucose 6-phosphate (Newshoume and RANDLE, 1961). In heart muscle or adipose tissue from normal rats insulin increased glucose uptake, glucose 6- and fructose 6-phosphate concentrations and (in adipose tissue) carbon flow from glucose to glyceride glycerol and glycerol. In this instance the rate of between glycerol phosphate concentration and esterification rate which they show. Adrenaline accelerated esterification in adipose tissue in spite of a substantial fall in the concentration of glycerol phosphate.

In summary these results appear to show that when. insulin acts on heart muscle or adipose tissue in the

Table 1. Concentrations of hexose monophosphates and glycerol phosphate and rates of glucose uptake and carbon flow from glucose to glyceride glycerol and glycerol in rat heart and epididymal adipose tissue

Details are as given by Denton et al. (1966), Dentos and Randue (1967), Randee et al. (1964a) and GARLAND and RANDLE (1964b)

\begin{tabular}{|c|c|c|c|c|c|c|}
\hline \multirow[b]{2}{*}{ Tissue and animal } & \multirow[b]{2}{*}{ Insulin } & \multicolumn{3}{|c|}{ Concentration. $\mu$-moles/gm wet tissue, } & \multicolumn{2}{|c|}{$\begin{array}{l}\text { Rate } \mu \text {-moles } / \mathrm{gm} / \mathrm{h} \text { or } \mu \text {-atoms } \\
\text { carbon } / \mathrm{gm} / \mathrm{h}^{\mathrm{a}}\end{array}$} \\
\hline & & $\begin{array}{l}\text { glucose 6- } \\
\text { phosphate }\end{array}$ & $\begin{array}{l}\text { fructose } 6- \\
\text { phosphate }\end{array}$ & $\begin{array}{l}\text { glycerol- } \\
\text { phosphate }\end{array}$ & $\begin{array}{l}\text { glucose } \\
\text { uptake }\end{array}$ & $\begin{array}{l}\text { carbon flow, } \\
\text { glucose to glyce- } \\
\text { ride glycerol }+ \\
\text { glycerol }\end{array}$ \\
\hline \multirow[t]{2}{*}{ Normal rat heart } & - & 15 & 4.1 & 5.5 & 1.8 & - \\
\hline & + & 32 & 6.8 & 16.2 & 10.6 & 0.19 \\
\hline \multirow{4}{*}{$\begin{array}{l}\text { Diabetic rat heart } \\
\text { Normal rat epidi- } \\
\text { dymal adipose } \\
\text { tissue }\end{array}$} & + & 51 & 8.8 & 6.7 & 3.8 & 0.71 \\
\hline & & & & & & \\
\hline & - & 0.22 & - & 0.12 & $6.0^{\mathrm{a}}$ & $1.8^{\mathrm{a}}$ \\
\hline & + & 0.57 & - & 0.78 & $57.6^{\mathrm{a}}$ & $4.1^{\mathrm{a}}$ \\
\hline \multirow{3}{*}{$\begin{array}{l}\text { ditto + adrenaline } \\
\text { Normal adipose } \\
\text { tissue }\end{array}$} & + & 0.31 & - & 0.17 & $60.8^{\mathrm{a}}$ & $19.8^{a}$ \\
\hline & & & & & & \\
\hline & + & 0.96 & - & 2.60 & $75^{\mathrm{a}}$ & $4.3^{\mathrm{a}}$ \\
\hline $\begin{array}{l}\text { Diabetic adipose } \\
\text { tissue }\end{array}$ & + & 0.67 & - & 3.30 & $31^{\mathrm{a}}$ & $6.4^{\mathrm{a}}$ \\
\hline
\end{tabular}

glucose uptake may have determined the concentration. of glycerol phosphate and the rate of esterification of fatty acid (as measured by carbon flow). When insulin acts on normal muscle or adipose tissue its effects on glucose uptake may thus contribute to a diminution in free fatty acid release.

In hearts from alloxan-diabetic rats perfused with media containing insulin, glucose uptake and glycerol phosphate concentration were reduced. It seems unlikely that the diminution in glycerol phosphate concentration was a consequence of the diminished uptake of glucose. The concentrations of glucose 6- and fructose 6-phosphates were increased in spite of the reduction in glucose uptake. The changes in the concentrations of glycerol phosphate, glucose 6-phosphate and fructose 6-phosphate have been attributed to inhibition of PFK by citrate accumulation and to a diminished cytoplasmic ratio of $\mathrm{NADH}_{2} / \mathrm{NAD}$ (RANDLE et al., 1966). Moreover the fall in glycerol phosphate concentration did not lead to a diminution in the rate of re-esterification of fatty acid. The flow of carbon from glucose to glyceride glycerol and glycerol was increased in the diabetic muscle.

In epididymal adipose tissue from alloxan-diabetic rats incubated in media containing insulin, glucose uptake and glucose 6-phosphate concentration were reduced. The concentration of glycerol phosphate was, however, unchanged and the rate of esterification of fatty acid as measured by the flow of carbon from glucose to glyceride glycerol and glycerol was increased. The effects of adrenaline on adipose tissue are also included in the table because of the striking dissociation normal rat the glycerol phosphate concentration and the rate of esterification may be increased as a consequence of accelerated glucose uptake. In alloxandiabetes the concentration of glycerol phosphate in muscle may fall but this is not a consequence of diminished glucose uptake nor does it lead to any diminution in the rate of re-esterification of fatty acids. In adipose tissue alloxan-diabetes did not diminish the concentration of glycerol phosphate or the rate of esterification. These findings are inconsistent with the idea that fatty acid release and oxidation are accelerated because glucose uptake is diminished. They support the view that increased lipolysis is primarily responsible for the accelerated release of fatty acids from adipose tissue and muscle glycerides and for the augmented rate of oxidation of fatty acids in muscle in alloxan-diabetes in the rat. The same would appear to be true for diabetes induced accutely in the rat by injection of insulin anti-serum (TARRANT et al., 1964).

\section{Diabetes and the concentration of lipids in muscle}

In a number of early studies with the heart-lung preparation the measurement of respiratory quotient and some analyses of cardiac lipids suggested that these may be used to support respiration (EVANs, 1913 -14; Bayliss et al., 1928; Visscher and Mulder, 1930; CruickshaNk and StaRtup, 1934 ; CRUiCKshank and MoLure, 1936; Cruickshank and Kosterlitz, 1941). The presence of blood lipids in these preparations may however have vitiated clear interpretation. In a number of studies with the perfused rat heart it has become clear that the oxidation of carbohydrate (gly- 
cogen or glucose) is insufficient to account for the oxygen consumed. Thus it has been found in our own studies that in the normal heart perfused without substrate the oxidation of glycogen accounts for only 20 per cent of the oxygen consumed. With glucose and insulin in the medium oxidation of glucose accounts for 80 per cent of the oxygen consumed in the normal heart and for 50 per cent in the alloxan-diabetic rat heart. The data of SCHARFF and WooL (1965) suggest that the utilisation of endogenous amino acids is too small to account for the surplus oxygen consumption. It has seemed likely that the breakdown of lipid and oxidation of the fatty acids released account for the residual oxygen consumption.

Definite evidence for the disappearance of cardiac lipids during perfusion has been obtained by direct analyses (ShIPP et al., 1964; Denton and RANDLE, 1965, 1967). Evidence that these lipids are present in muscle cells and not in adipose tissue cells sequestered by the muscle sample is provided by the electron microscopic studies of rat heart by ORTH and MorgaN (1962); by the high glycerol output of cardiac muscle and the high acyl CoA concentration (GARLAND and RANDLE, 1964 b).

The concentration of phospholipid in rat heart (34 $\mu$-moles/gm wet muscle) was much greater than that of triglyceride $(2.5 \mu$-moles $/ \mathrm{gm})$ but as will be seen it is

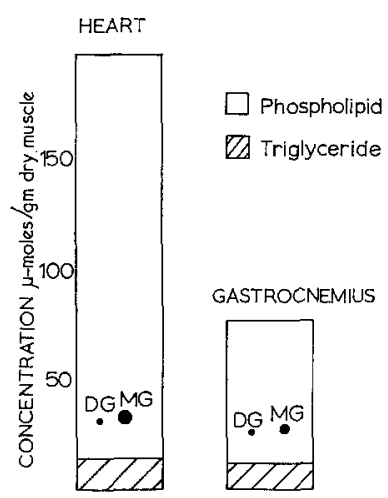

Fig. 6. Triglyceride and phospholipid concentrations in normal rat heart and gastrocnemius Concentrations represented by areas. Data of DHNTON and RAIDLE (1965). DG $=$ diglyceride; $\mathrm{MG}=$ monoglyceride

the triglyceride fraction which shows the greatest fluctuations in diabetes. Analyses of gastrocnemius, taken as representative of skeletal muscles gave similar results though the concentration of phospholipid was somewhat lower (Fig. 6). After perfusion of normal hearts without substrate for 60 min the concentration of triglyceride was reduced by 50 per cent (Table 2). There was no significant change in the concentration of phospholipid though it should be emphasised that this does not preclude the possibility that the breakdown of phospholipids may have contributed some fatty acids to respiration as suggested by SHIPP et aul. (1963). The breakdown of phospholipid expected $(<10$ per cent) would be difficult to detect.
In alloxan-diabetic rats the concentration of triglyceride in cardiac muscle and gastrocnemius was increased substantially. There was no detectable change in phospholipid concentration. This increase in triglyceride concentration was not dependent on dietary lipid; a comparable increase was seen in heart muscle from alloxan-diabetic rats fed for $48 \mathrm{~h}$ on a fat free (rice) diet. Moreover total starvation for $48 \mathrm{~h}$ produced some increase in triglyceride concentration in cardiac

Table 2. Triglyceride and phospholipid utitisation in rat heart For details see Denton and RardLe (1965, 1967). Six observations in each group

\begin{tabular}{lcc}
\hline Normal rat heart: & \multicolumn{2}{c}{$\begin{array}{l}\text { Concentration. } \mu \text {-moles/gm dry } \\
\text { weight. Mean } \pm \text { st. error }\end{array}$} \\
\cline { 2 - 3 } & Triglyceride & Phospholipid \\
\hline 2 min perfusion & $18.7 \pm 0.8$ & $186 \pm 6$ \\
$\begin{array}{l}60 \text { min perfusion without } \\
\text { substrate }\end{array}$ & $8.7 \pm 0.7$ & $171 \pm 7$
\end{tabular}

Table 3. Lipid Concentrations in Rat Heart: Effect of Diabetes

For details see Dentox and Rander (1965, 1967). Six observations in each group

\begin{tabular}{lcccc}
\hline Tissue and animal & \multicolumn{4}{c}{ Concentration. $\mu$-moles/gm. dry muscle } \\
\cline { 2 - 5 } & $\begin{array}{l}\text { Tri- } \\
\text { glyceride }\end{array}$ & $\begin{array}{l}\text { Di- } \\
\text { glyceride }\end{array}$ & $\begin{array}{l}\text { Mono- } \\
\text { glyceride }\end{array}$ & $\begin{array}{l}\text { Phospho- } \\
\text { lipid }\end{array}$ \\
\hline Rat Heart: & & & & \\
Normal & 13.6 & 0.1 & 0.6 & 184 \\
Alloxan-diabetic & 28.2 & 0.6 & 0.7 & 163 \\
Hypox & 10.3 & 0.4 & 0.7 & $\mathbf{1 4 3}$ \\
Hypox-diabetic & 10.6 & 0.3 & 0.7 & $\mathbf{1 5 4}$ \\
Hypox-diabetic; & 22.9 & - & - & $\mathbf{1 4 2}$ \\
$\quad$ GH + cortisol & & & & \\
Rat Gastrocnemius: & & & & 64 \\
Normal & 12 & 0.1 & 0.4 & 63 \\
Diabotic & 26 & 0.4 & 0.5 & 6
\end{tabular}

Table 4. Glyceride and phospholipid concentrations in rat heart

Effects of alloxan-diabetes with fat-free diet and effects of starvation. For details see DeNTON and RANDLF (1965). Glyceride is Tri + Di + Monoglyceride in which Triglyceride accounted for $95 \%$. Six hearts in each group

\begin{tabular}{lcc}
\hline Animal & \multicolumn{2}{c}{ Concentration. $\mu$-moles/gm dry } \\
& \multicolumn{2}{c}{ muscle. Mean \pm st. error } \\
\hline Glyceride & Phospholipid \\
\hline Normal fed (fat free diet) & $14.0 \pm 1.4$ & $182 \pm 7.7$ \\
Alloxan diabetic (fat free & & \\
$\quad$ diet) & $28.7 \pm 2.1$ & $161 \pm 7.7$ \\
Normal fed & $20.3 \pm 2.1$ & $182 \pm 9.1$ \\
Starved 48 h & $27.3 \pm 2.1$ & $168 \pm 9.8$
\end{tabular}

muscle from normal rats. The increase in triglyceride concentration induced by alloxan-diabetes was dependent upon actions of growth hormone and corticosteroids. In hypophysectomised rats induction of alloxan diabetes produced no increase in muscle 
triglycerides unless growth hormone and cortisol were given by injection. The change in triglyceride concentration shows the same hormone dependence as alterations in the rate of lipolysis and in the activities of phosphofructokinase and hexokinase in cardiac muscle in alloxan-diabetes. These results, summarised in Tables 3 and 4 suggest that the increased triglyceride concentrations in the diabetic heart or gastrocnemius may be brought about by the transfer of fatty acids from adipose tissue glycerides to muscle glycerides. They suggest that notwithstanding the diminished uptake of glucose and the diminished concentration of glycerol phosphate in skeletal and cardiac muscle in the alloxan-diabetic rat in vivo, the rate of esterification of plasma free fatty acids to triglycerides may be accelerated. The in vitro measurements of the rate of re-esterification of fatty acids in the heart given in Table 1 are consistent with this interpretation. An alternative possibility, perhaps less likely but not excluded is that plasma triglyceride may enter the muscle glyceride fraction without hydrolysis and that this is accelerated in diabetes.

\section{General conclasions}

Current knowledge of the changes which may occur in the interrelationships between glucose and lipid metabolism after the development of alloxan-diabetes in the rat is summarised in Fig. 7. In adipose tissue

\section{MUSCLE BLOOD FAT}

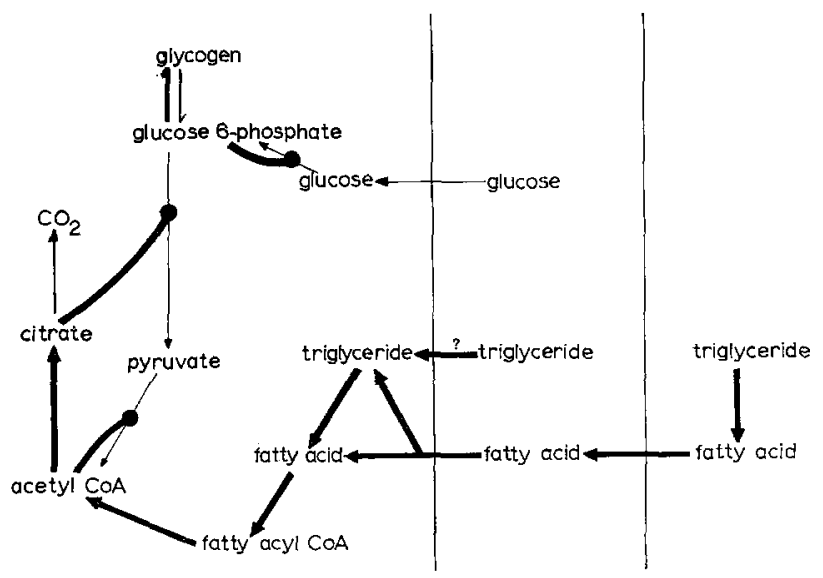

Fig. 7. Modifications in the interrelationships of carbohydrate and lipid metabolism in the alloxan-diabetic rat

Reactions of feedback inhibitions which are accentuated are indicated by thick lines. Reproduced by courtesy of Recent Progress in Hormone Research.

the actions of growth hormone and corticosteroids lead, in the absence of insulin, to an increased rate of lipolysis perhaps through the synthesis of additional lipase(s) (FAIN et al., 1965). As a consequence free fatty acids are released to blood plasma at a greater rate and the plasma concentration increases. The oxidation of fatty acids is accelerated and the rate of esterification of fatty acids to triglyceride is augmented leading to an increase in triglyceride concentration in the muscle. As a result, either of the actions of growth hormone and corticosteroids or possibly of an increased triglyceride concentration, lipolysis in muscle is accelerated. This may be an important factor in the increased rate of fatty acid oxidation in the diabetic muscle. The oxidation of fatty acid to acetyl CoA at an increased rate may lead through mechanisms which have been detailed to inhibition of pyruvate dehydrogenase, phosphofructokinase and hexokinase.

There are a number of points in the scheme outlined in Fig. 7 which need confirmation in detail. As mentioned earlier the role of growth hormone and corticosteroid in the inhibition of PDH needs to be defined and the possibility that the concentration of PDH is reduced in the diabetic muscle (as opposed to being inhibited) has not been excluded. In the case of PFK and HK evidence on these points has been detailed (Newsholme and Randet, 1964 ; REGEN et al., 1964; Pogson and RandLe, 1966a, b; RandLe et al., 1966). The factors which diminish the cytoplasmic ratio of $\mathrm{NADH}_{2} / \mathrm{NAD}$ in muscle in diabetes require clarification and the enzymic mechanisms which control triglyceride synthesis and breakdown in diabetic muscle and adipose tissue are poorly defined. It is perhaps unlikely, however, that resolution of these points will modify the present conclusion that deficiencies in the utilisation of glucose in muscle and adipose tissue do not play a major role in the increased rate of fatty acid oxidation in muscle in this form of experimental diabetes.

\section{Minkowski and Diabetes Research}

It is perhaps not entirely inappropriate to conclude the first lecture in honour of MrskowskI and his unique contribution to research in diabetes with a brief biographical note and a personal tribute. The picture of MrNkowskI which is reproduced by courtesy of the "Münchener Medizinische Wochenschrift" is well known. Oskar Minkowski was born in Alexoten in the province of Kovno in 1858 . He studied medicine at Strassburg and Freiburg after an earlier period of education at Königsberg to which he returned to take his doctors degree with NAUNYN. He moved, with NaUnyN, to Strassburg in 1888. In 1905 he was appointed Professor of Medicine at Greifswald and in 1909 to the Chair at Breslau. He retired in 1926 four years after the publication of the discovery of insulin by BANTING and BEST.

In 1889, with VON MERING, Minkowski discovered that surgical extirpation of the pancreas leads to the development of diabetes. Like the discovery of insulin which was to follow, the observation was of such immediate importance and so well founded experimentally as to brook little argument. BANTING's contribution to knowledge and to the health of diabetic patients has been recognised in a number of lectures 
and awards and some of the material presented in this lecture formed the basis for parts of one of these. The discovery which Minkowski made with von Mering in 1889 was instrumental in leading to the discovery of insulin. I am glad that the European Association for the Study of Diabetes and its benefactor Farbwerke Hoechst have afforded Minkowski this recognition and that the foresight of my parents has qualified me on account of my age to give this tribute to his work.

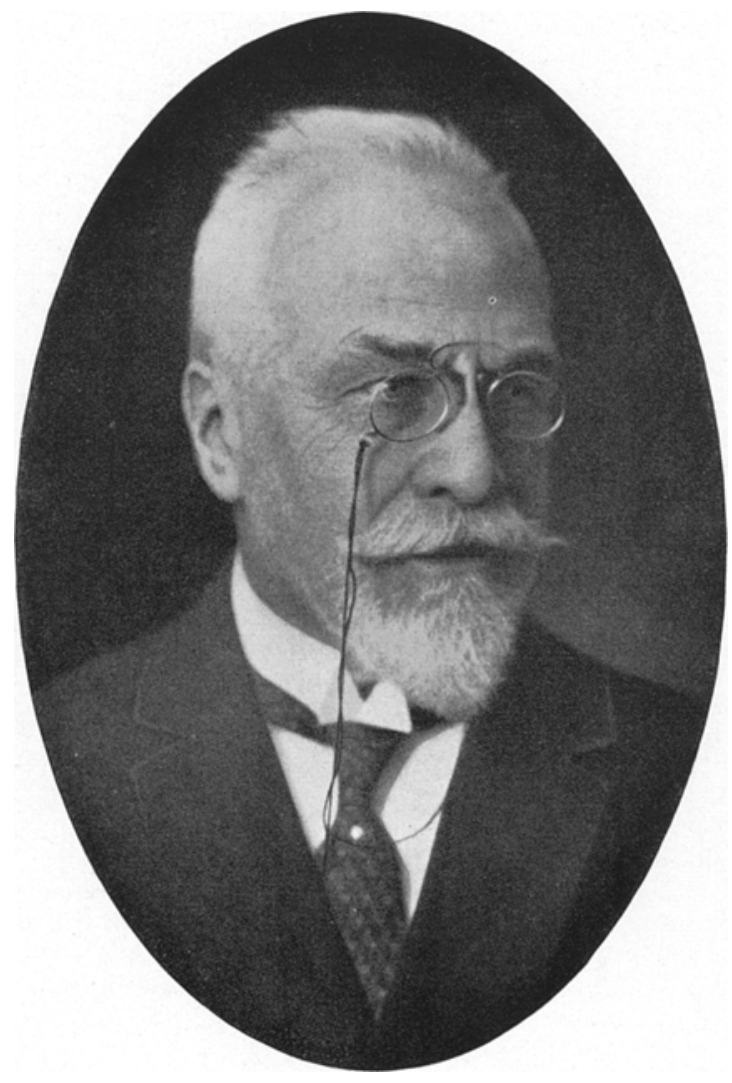

Oskar Mixkowski (1858-1931) Reproduced by courtesy of "Münchene Medizinische Wochenschrift" "

\section{References}

Baddiley, J.: The Structure of Coenzyme A. Advanc. Enzymol. 16, 1-- 21 (1955).

Bayliss, L.E., E.A. Muller and E.H. Starling: The action of insulin and sugar on the respiratory quotient and metabolism of the heart-lung preparation. J. Physiol. 65, 33-47 (1928).

Camili, G.F.Jr., B. Jeankenaud, B. Lmboeur and A. E. RENOLD : Effects of insulin on adipose tissue. Ann. N.Y. Acad. Sci. 82, 403-411 (1959).

CruiokshaitK, E.W.H., and H.W. Kosterlitz: The utilisation of fat by the aglycaemic mammalian heart. J. Physiol. 99, 209-223 (1941).

-, and G.S. MoLure: On the question of the utilisation of amino acids and fat by the mammalian heart. J. Physiol. 86, 1-14 (1936).

-, and C.W. STARTUP: The action of insulin on the R.Q., oxygen utilisation, $\mathrm{CO}_{2}$ production and sugar utilisation in the mammalian diabetic heart. J. Physiol. 81, 153161 (1934).
Denton, R.M., and P.J. Randue: Hormonal control of lipid concentration in rat heart and gastrocnemius. Nature, 208, 488 (1965).

- Citrate and the regulation of adipose tissue phos. phofructokinase. Biochem. J. 100, 420-423 (1966).

- - The measurement of carbon flow from glucose and glycogen-glucose to glyceride-glycerol in rat heart and epididymal adipose tissue; effects of insulin, adrenaline and alloxan-diabetes. Biochem. J. submitted for publication (1967).

- R.E. Yorke and P.J. RANDLE: Measurements of concentrations of metabolites in adipose tissue and effects of insulin, diabetes and adrenaline. Biochem. J. 100, $401-419$ (1966).

DoLE, V.P.: A relation between non-esterified fatty acids in plasma and the metabolism of glucose. J. clin. Invest. $35,150-154$ (1956).

DruRY, D.R., and A.N. WIOK: Can other fuels substitute for glucose in tissues subjected to intense insulin activity? Ciba Foundation Colloquia Endocrin. 6, 211 $217(1953)$.

Evans, C.L.: The effect of glucose on the gaseous metabolism of the isolated mammalian heart. J. Physiol. (London) 47, 407-418 (1913-1914).

Evans, J.R., L.H. OpIE and A.E. Reinold: Pyruvate metabolism in the perfused rat heart. Amer. J. Physiol. 205, $971-976$ (1963).

FAIN, J.N., V.P. KovaceV and R.O. Scow: Effect of growth hormone and dexamethasone on lipolysis and metabolism in isolated fat cells of the rat. J. biol. Chem. 240, 3522-3529 (1965).

GARLAND, P.B., and P.J. RANDLe: A rapid enzymatic assay for glycerol. Nature 196, 987-988 (1962).

- Effects of alloxan-diabetes and adrenaline on concentrations of free fatty acids in rat heart and diaphragm muscles. Nature 199, 381-382 (1963).

- - Control of pyruvate dehydrogenase in the perfused rat heart by the intracellular concentration of acetyl CoA. Biochem. J. 91, 6C-7C (1964a).

- - Regulation of glucose uptake by muscle. 10. Effects of diabetes, starvation, hypophysectomy and adrenalectomy and fatty acids, ketone bodies and pyruvate on glycerol output and concentrations of free fatty acids, long chain fatty acyl CoA, glycerol phosphate and citrate cycle intermediates in rat heart and diaphragm uscles. Biochem. J. 93, 678-687 (1964b).

- E.A. Newsholme and P.J. Randue: The effect of fatty acids, ketone bodies, starvation and diabetes on pyruvate metabolism in rat heart. Nature 195, 381$383(1962)$.

- P.J. Randle and E.A. Newsholme: Citrate as an intermediary in the inhibition of phosphofructokinase in rat heart muscle by fatty acids, ketone bodies, pyruvate, diabetes and starvation. Nature 200, 169$170(1963)$.

- E.A. Newsholme and P.J. RandLe: Regulation of glucose uptake by muscle. 9. Effects of fatty acids and ketone bodies and diabetes and starvation on pyruvate metabolism and lactate to pyruvate and L-glycerol 3 -phosphate to dihydroxyacetone phosphate ratios in rat heart and rat diaphragm muscles. Biochem. J. 93, $665-677(1964)$.

Gondon, R.S. Jr., and A. Cherkes: Unesterified fatty acids in human blood plasma. J. clin. Invest. 35, 206$212(1956)$.

- - Production of unesterified fatty acids from isolated rat adipose tissue incubated in vitro. Proc. Soc. exp. Biol. 97, 150-151 (1958).

Hales, C.N., and P.J. RandeE: Effects of low carbohydrate diet and diabetes mellitus on plasma concentrations of glucose, non-esterified fatty acid and insulin 
during oral glucose-tolerance tests. Lancet, 1963, 790794.

Hausberger, F.X., S.W. Milstein and R.J. Rutmax: The influence of insulin on glucose utilisation in adipose and hepatic tissues in vitro. J. biol. Chem. 208, 431438 (1954).

Hollenberg, C.H., M.S. Raben and E.B. Astwood: The lipolytic response to corticotropin. Endocrinology $68,589-598(1961)$.

JUNGAS, R.L., and E.G. BAIL: Studies on the metabolism of adipose tissue. XII. The effects of insulin and epinephrine on free fatty acid and glycerol production in the presence and absence of glucose. Biochemistry 2, 383388 (1963).

KrPNis, D.M.: Regulation of glucose uptake by muscle: functional significance of permeability and phosphorylating activity. Ann. N.Y. Acad. Sci. 82, 354-366 (1959).

KRAHI, M.E.: The effect of insulin and pituitary hormones on glucose uptake in muscle. Ann. N.Y. Acad. Sci. 54, 649-670 (1951).

Krebs, H.A.: Metabolism of amino-acids. III. Deamination of amino-acids. Biochem. J. 29, 1620-1644 (1935).

LAURELI, S.: Plasma free fatty acids in diabetic acidosis and starvation. Scand. J. elin. Lab. Invest. 8, 81-82 (1956).

Leboeut, B., R. B. FuIN and G.F. CAmILI, Jr.: Effect of epinephrine on glucose uptake and glycerol release by adipose tissue in vitro. Proc. Soc. exp. Biol. 102, 527$529(1959)$.

Lipmand, F.: Acetyl Phosphate. Advances in Enzymol. 6, 231-237 (1946).

- Development of the acetylation problem, a personal account. Science 120, 855-865 (1954).

LYNEN, F.: Acetyl Coenzyme A and the "fatty acid cycle". Harvey Lect. 48, 210-244 (1952-3).

- E. ReicherT and L. RuefF: Zum Biologischen Abbau der Essigsäure. VI. Activierte Essigsäure; ihre Isolierung aus Hefe und ihre Chemische Natur. Ann. Chem. $574,1-32$ (1951).

LYNN, W.S., R.M. MCLEOD and R.H. BRows: Effeets of epinephrine, insulin and corticotrophin on the metabolism of rat adipose tissue. J. biol. Chem. 235, 1904$1911(1960)$.

Mahler, R., W.S. STaftord, M.E. Tarrant and J. Ashmore: The effect of insulin on lipolysis. Diabetes 13, $297-302(1964)$.

Morgan, H.E., E. Cadenas, D.M. Regen and C.R. PaRk: Regulation of glucose uptake in muscle. IT. Rate limiting steps and effects of insulin and anoxia in heart muscle from diabetic rats. J. biol. Chem. 236, 262-268 (1961).

Newsholime, E.A., and P.J. Randue: Regulation of glucose uptake by muscle. 5. Effects of anoxia, insulin, adrenaline and prolonged starving on concentrations of hexose phosphates in isolated rat diaphragm and perfused isolated rat heart. Biochem. J. 80, 655-662 (1961).

- - and K.L. Manchester: Inhibition of the phosphofructokinase reaction in perfused rat heart by respiration of ketone bodies, fatty acids and pyruvate. Nature $\mathbf{1 9 3}, 270-271$ (1962).

- - Regulation of glucose uptake by muscle. 7. Effects of fatty acids, ketone bodies and pyruvate, and diabetes and starvation, hypophysectomy and adrenalectomy on concentrations of hexose phosphates, nucleotides and inorganic phosphate in perfused isolated rat heart. Biochem. J. 93, 641-651 (1964).

Nicholls, D.G., and P.B. Gartand: Continuous recording techniques for oxygen uptake and carbon dioxide output applied to the study of pyruvate oxidation by rat liver mitochondria. Biochem. J. 100,

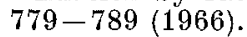

Orth, D.N., and H.E. Morgan: The effect of insulin, alloxan-diabetes, and anoxia on the ultrastructure of the rat heart. J. Cell. Biol. 15, 509-523 (1962).

Park, C.R., H.E. Morgan, M.J. Henderson, D.M. REGeN, E. Cadenas and R.L. Post: The regulation of glucose uptake in muscle as studied in the perfused rat heart. Recent Progr. Hormone Res. 17, 493-529 (1961).

Parmeggiani, A., and R.H. Bowman: Regulation of phosphofructokinase activity by citrate in normal and diabetic muscle. Biochim. biophys. Res. Comm. 12, $268-273(1963)$.

Passonneau, J.V., and O.H. Lowry: Phosphofructo. kinase and the Pasteur effect. Biochim. biophys. Res. Comm. 7, 10 -1 15 (1962).

Pearson, O.H., C.K. Hsteh, C.H. Du Tolt and A.B. HASTINGS: Metabolism of cardiac muscle: utilisation of $\mathrm{C}^{14}$ labelled pyruvate and acetate in diabetic rat heart. Amer. J. Physiol. 158, $261-268$ (1949).

Pogson, C.I. and P.J. Rander: The control of rat heart phosphofructokinase by citrate and other regulators. Biochem. J. 100, 683-693 (1966a).

- - The effects of alloxan-diabetes, starvation and hypophysectomy on total phosphofructokinase activity in rat heart. Nature In press $(1966 \mathrm{~b})$.

Rande, P.J., P.B. Garland, C.N. Hales and E.A. Newsholme: The glucose fatty acid cycle. Lancet $\mathbf{1 9 6 3}$, I, $785-790$.

- E.A. Newshoume and P.B. Garland : Regulation of glucose uptake by muscle. 8. Effects of fatty acids, ketone bodies and pyruvate, and diabetes and starvation on uptake and metabolic fate of glucose in rat heart and diaphragm muscles. Biochem. J. 93, 652664 (1964a).

- P.B. Garland, C.N. Hales and E.A. Newsholme: The glucose fatty acid cycle and Diabetes Mellitus. Ciba Foundation Colloquia Endocrin. 15, 192-212 (1964b).

- $-\ldots$ R.M. DenTon and C.I. Pogson: Interactions of metabolism and the physiological role of insulin. Recent Progr. Hormone Res. 22, 1 (1966).

Regen, D.M., W.W. Davies, H.E. Morgan and C.R. PARK: The regulation of hexolkinase and phosphofructokinase activity in heart muscle. J. biol. Chem. 239, $43-48$ (1964).

Renold, A.E., O.B. Croftord, W. Stadthacher and B. JEANRENAUD: Hormonal control of adipose tissue metabolism, with special reference to the effects of insulin. Diabetologia 1, 4-12 (1965).

Rizack, M.A.: An epinephrine sensitive lipolytic activity in adjpose tissue. J. biol. Chem. 236, 657-662 (1961).

SohARFF, R., and I.G. Wool: Accumulation of amino acids in muscle of perfused rat heart. Effect of insulin. Biochem. J. 97, 257-271 (1965).

ShIPP, J.C., L.H. OpIe and D.R. Chaldoner: Fatty acid and glucose metabolism in the perfused rat heart. Nature 189, 1018-1019 (1961).

- J.M. Thomas and L. Crevasse: Oxidation of $\mathrm{C}^{14}$ labelled endogenous lipids by isolated perfused rat heart. Seience 143, 371-373 (1964).

Smith, S.W., S.B. Weiss and E.P. Kennedy: The enzymatic dephosphorylation of phosphatidic acids. J. biol. Chem. 228, 915-922 (1957).

Tarrant, M.E., R. Mameer and J. Ashmore: Studies in experimental diabetes. IV. Free fatty acid mobilisation. J. biol. Chem. 239, 1714-1719 (1964).

Villee, C.A., and A.B. HAstings: The utilisation in vitro of $\mathrm{C}^{14}$ labelled acetate and pyruvate by diaphragm muscle of rat. J. biol. Chem. 181, 131-139 (1949). 
Visscher, M.B., and A.G. Mulder: The carbohydrate metabolism of the heart. Amer. J. Physiol. 94, 630640 (1930).

WeIss, S.B., and E.P. KENNEDY: The enzymatic synthesis of triglycerides. J. amer. chem. Soc. 78, 3550 (1956).

WERTHEIMER, E., and E. SHAFRIR: Influence of hormones on adipose tissue as a center of fat metabolism. Recent Progr. Hormone Res. 16, 467-490 (1960).

- , and B. Shapiro: The physiology of adipose tissue. Physiol. Rev. 28, 451-464 (1948).

WIELAND, O., and M. SUyter: Glycerokinase: Isolierung und Eigenschaften des Enzyms. Biochem. Z. 329, 320331 (1957).
Williamson, J.R., and H.A. Krebs. Acetoacetate as fuel of respiration in the perfused rat heart. Biochem. J. 80, $540-547$ (1961).

WhITE, J.E., and F.L. ENGEL: A lipolytic action of epinephrine and norepinephrine on rat adipose tissue in vitro. Proc. Soc. exp. Biol. 99, 375-378 (1958).

Professor Philif J. Randee M.A., Ph.D., M.D., M.R.C.P.

Department of Biochemistry

University of Bristol

Bristol 8, England 